\title{
CERTAIN ASPECTS OF TRAINING FUTURE MEDICAL SPECIALISTS ON THE BASIS OF INTERDISCIPLINARY INTEGRATION
}

\author{
Natalia Kalyniuk \\ $\mathrm{PhD}, \mathrm{JuD}$, Assosiate Professor of the Department of Pedagogy of the \\ Higher School and Social Sciences, I. Horbachevsky Ternopil \\ National Medical University, Ternopil, Ukraine. \\ Nataliia Maika \\ $\mathrm{PhD}, \mathrm{JuD}$, Instructor of the Department of Civil Law and Process, \\ Western Ukrainian National University, Ternopil, Ukraine. \\ Igor Rogalskyi \\ PhD, MD, Associate Professor of the Department of Pediatrics of \\ The Faculty of Postgraduate Education, I. Horbachevsky \\ Ternopil National Medical University, Ternopil, Ukraine.

\section{Taras Kadobnyi} \\ $\mathrm{PhD}$, Associate Professor of the Department of Pedagogy of \\ The Higher School and Social Sciences, I. Horbachevsky \\ Ternopil National Medical University, Ternopil, Ukraine.
}

\section{Olena Lototska}

DSc, PhD, MD, Professor of General Hygiene and Ecology Department, Ternopil State Medical University, Ternopil, Ukraine.

\begin{abstract}
It has been substantiated that interdisciplinary integration is one of effective ways of increasing education quality. The interdisciplinary approach based on new educational standards involves, above all, the ability of the medical education receiver to solve problems and take responsibility; to act in unstable context; student's motivation to study certain discipline, grounded comprehension and comparison; using obtained knowledge in practice; expanding horizons, increasing independence and creativity of future medical specialists; integration of the acquired knowledge, abilities and skills into one whole and perception of the material mastered during all training as inseparable unity. The importance of using interdisciplinary integration during training of future specialists in medical field, on the example of combination of clinical, bioethical and legal knowledge, has been substantiated. The question of using
\end{abstract}


interdisciplinary integration in the process of medical students training has been revealed. Factors for optimizing the process of training of future medical specialists on the basis of interdisciplinary links have been considered. It has been shown that use of interdisciplinary integrative technologies provides grounds for the formation and development of analytical and critical thinking in future medical specialists, which is the key to improving the level of medical education quality. It has been proved that vocational training of future specialists in medical field is in dynamic development, due to the priority of improving the level of quality of medical education. It has been found that the effectiveness of the integration approach in the process of training of future medical specialists, in order to improve the quality of their education, requires improvement of the methodical concept in the development of educational and methodological complex of vocational training of specialists on the basis of interdisciplinary integration. This can be ensured by considering the following factors: social demands to professional activity; specifics of training at clinical departments and features of mastering non-profile disciplines; providing scientific, informational and methodical accompanying of educational process; formation and development of analytical and critical types of thinking in future medical specialists. The proposed above will ensure high-quality readiness of future medical specialists for their professional activities.

Keywords: Interdisciplinary integration, vocational training, higher education, education quality, medical student.

Cite this Article: Natalia Kalyniuk, Nataliia Maika, Igor Rogalskyi, Taras Kadobnyi and Olena Lototska, Certain Aspects of Training Future Medical Specialists on the Basis of Interdisciplinary Integration, International Journal of Management, 11(9), 2020, pp. 939-946.

http://www.iaeme.com/IJM/issues.asp?JType=IJM\&VType=11\&IType=9

\section{INTRODUCTION}

An education quality is a priority direction of this in modern society, which develops in the conditions of globalization and use of information technologies. This criterion is one of the most important orientations in determining authority and competitiveness of higher education institutions. The same applies to the effectiveness of the modern system of training of future medical specialists.

Question about analysis of one or another pedagogical phenomena and processes, ensuring the quality of education have been studied in scientific works by such scientists as $\mathrm{A}$. Vykhrushch [10, p. 172], T. Horpinich [1, p. 103; 6, p. 132], N. Yelahina [1, p. 106], N. Kalyniuk [2], I. Melnychuk [4, p. 130], P. Mykytenko [5, p. 26], I. Rohalskyi [2], L. Romanyshyna [3, p. 918], N. Fedchyshyn [12, p. 120], and others. However, a large amount of research conducted by them indicates the need to improve the quality of education in general, and in medical education in particular.

Qualitative education nowadays, first of all, is those, which meets the requirements of the information society and forms in receiver those competencies, which are the most important in today's changing labor market. Within a realization of the Bologna process requirements on the territory of Ukraine education quality should be considered as a legal guarantee of a person's right to education, which is characterized by set of certain properties of educational services that determine its suitability to meet certain needs in accordance with their purpose and meet the characteristics of peculiarity, reliability, durability, the level of a determined standardization and unification. 
One of effective ways of increasing education quality is interdisciplinary integration. The interdisciplinary approach based on new educational standards involves, above all, the ability of the medical education receiver to solve problems and take responsibility; to act in unstable context; student's motivation to study certain discipline, grounded comprehension and comparison; using obtained knowledge in practice; expanding horizons, increasing independence and creativity of future medical specialists; integration of the acquired knowledge, abilities and skills into one whole and perception of the material mastered during all training as inseparable unity. Hence the need for new descriptors of the National Qualifications Framework in accordance with the Qualifications Framework of the European Higher Education Area by categories: autonomy and responsibility, knowledge, communication, integration, abilities.

The purpose of article. To substantiate the importance of using interdisciplinary integration in the process of training of future specialists in medical field on the example of combining clinical, bioethical and legal knowledge; to outline the question of using interdisciplinary integration during medical students' training; to consider the factors for optimizing the process of training of future medical specialists on the basis of interdisciplinary links. It has been shown that use of interdisciplinary integrative technologies gives grounds for the formation and development of future medical specialists in the field of analytical thinking.

\section{RESEARCH METHODS}

To realize set purpose the following complex of methods has been applied: theoretical analysis, comparison, substantiation, generalization, systematization of theoretical and practical materials, study of major international and national normative-legal acts in the context of characteristics of the Physician's Oath during the training of future medical specialists on the basis of interdisciplinary integration; formulation and systematization of conclusions.

\section{RESEARCH RESULTS}

Reforming the healthcare system predetermine new requirements in the system of higher medical education and forming new type future specialists, which should master a specialty perfectly, have got skills of sociability, business communication, be able to adapt to today's requirements, focus on human rights in the field of health care during performing professional responsibilities. The identified problem includes necessity of introduction of the discipline "Medical Law of Ukraine" for students of higher medical educational institutions, and also elective courses such as "Legal Aspects of Certain Types of Medical Activity", "Human Rights in Health Care", "Legal Provision of Health Care", etc. And this is due to the integrative approach in vocational medical education is a methodological base of interdisciplinary integration. Moreover, interdisciplinary integration should be understood as the process of harmonizing the content of academic disciplines to reflect their unique, continuous and valuable phenomena of professional activity.

There is a use of integration approach to educational process during training of future specialists in medical field in the institutions of higher education, which consists in the logical sequence of introduction of academic disciplines. The main task of interdisciplinary integration is methodical processing of the essence of educational disciplines, which consists in systematization and generalization of the material obtained during their study. Use of integration approach in the process of training of future specialists in medical field should given on the example of the characteristics of the Physician's Oath of Ukraine, studied by students while mastering a number of disciplines, such as "Introduction to Specialty", "Bioethics", "Social Medicine", "Medical Law of Ukraine" will be used in professional activity in future. 
And this is for the reasons that modern development of technologies, scientific knowledge and practice of their implementation and application in the field of health care determines the legal, social, moral and ethical problems. International and legal standards in the sphere of biomedicine are always the initial source for national legislation. After all, the protection and observance of fundamental human rights and freedoms is not the competence of only individual country, but also the most important task of the entire international community. International standards in the sphere of biomedicine are universally recognized international legal norms that enshrine the status of the individual at the universal level and establish a list of fundamental rights and freedoms in the field of medicine and biology, the duty of the state to comply with them, and also the limits of their possible or compulsory restriction.

To describe the problems of international and legal standards in the sphere of biomedicine, the exceptional importance of doctors' participation in these legal relationships should be recognized. Fundamental international documents, which became basic for any professional doctor's activity, are the International Physician's Oath (1948) [8] and the International Code of Medical Ethics (1949) [9]. This is due to the fact that after obtaining a level of higher education in specialty of "Medicine", each graduate is required to take an oath of a doctor. The Physician's Oath of Ukraine is approved bylaw normative legal act - the Decree of the President of Ukraine of June 15, 1992, which was developed in accordance with international standards in the field of bioethics.

The doctor's profession always requires an increased level of humanism and moral principles among people, who choose this activity. Bioethics is closely related to law. The moral norms of professional behavior of doctors, established for millennia, are reflected in the legislative prescriptions. The unique of this profession led to the approval of bioethical principles at the international level that is the basis for a common understanding of the essence of the doctor's oath in different countries. The formality and solemnity of the procedure of taking the oath of a doctor generates respect, loyalty, pride, integrity and honesty in doctors' future professional activities. The procedure of taking the Physician's Oath of Ukraine meets the requirements of the international standards of bioethics. That is: the oath of a doctor must be given by all graduates of medical institutions of higher education; in a solemn atmosphere in the presence of their teaching staff and members of the public. Text of the Physician's Oath is proclaimed collectively and signed by the graduate and kept in his personal file. Thus, the mark on acceptance of the Physician's Oath is made in the diploma, the text of which is added in it. These standards of the Physician's Oath of Ukraine are consistent with international principles of bioethics with the following instructions: "treat your teachers with respect and gratitude" (Geneva Declaration, 1948); "doctor should behave with colleagues as he would like them to behave towards him"; "a doctor should not entice patients from colleagues" (International Code of Medical Ethics, 1949).

Principles of Geneva Declaration and the International Code of Medical Ethics lay down the responsibilities of doctors due to bioethical principles, which are transformed into the Physician's Oath of Ukraine. We try to show the comparative characteristics in the table 1.

Table 1 The comparative characteristics of the Physician's Oath of Ukraine with international legal standards in the field of bioethics

\begin{tabular}{|l|l|l|l|}
\hline Duty of doctor & $\begin{array}{c}\text { The Physician's } \\
\text { Oath of Ukraine } \\
\text { (1992) }\end{array}$ & $\begin{array}{c}\text { The International Code of } \\
\text { Medical Ethics (1949) }\end{array}$ & $\begin{array}{c}\text { The International } \\
\text { Physician's Oath (1948) }\end{array}$ \\
\hline $\begin{array}{l}\text { The duty to } \\
\text { give a timely } \\
\text { and qualified } \\
\text { medical care, to to }\end{array}$ & $\begin{array}{l}\text { "to give all } \\
\text { knowledge and forces } \\
\text { to protection and }\end{array}$ & $\begin{array}{l}\text { "selflessly provide competent } \\
\text { medical care with a full technical } \\
\text { and moral independence, with }\end{array}$ & $\begin{array}{l}\text { "to care, first of all, about } \\
\text { patient's health"; } \\
\text { "not allow circumstances, } \\
\text { related to age, state of health, }\end{array}$ \\
\hline
\end{tabular}



Integration

\begin{tabular}{|c|c|c|c|}
\hline Duty of doctor & \begin{tabular}{|c|}
$\begin{array}{c}\text { The Physician's } \\
\text { Oath of Ukraine } \\
(1992)\end{array}$ \\
\end{tabular} & $\begin{array}{l}\text { The International Code of } \\
\text { Medical Ethics (1949) }\end{array}$ & $\begin{array}{c}\text { The International } \\
\text { Physician's Oath (1948) }\end{array}$ \\
\hline \begin{tabular}{|l} 
promote the \\
protection and \\
strengthening \\
of human \\
health, \\
prevention and \\
treatment of \\
diseases
\end{tabular} & $\begin{array}{l}\text { human health, } \\
\text { treatment and } \\
\text { prevention of } \\
\text { diseases"; } \\
\text { "to be always ready } \\
\text { to provide medical } \\
\text { care" }\end{array}$ & $\begin{array}{l}\text { compassion and respect for } \\
\text { human dignity"; } \\
\text { "doctor always should remember } \\
\text { about the duty to preserve human } \\
\text { life"; } \\
\text { "to provide emergency care as } \\
\text { humanitarian duty, if there is no } \\
\text { certainty that others are willing } \\
\text { and able to provide this care" }\end{array}$ & $\begin{array}{l}\text { religion, race, sex, } \\
\text { nationality, political beliefs, } \\
\text { sexual orientation or social } \\
\text { status, to prevent the } \\
\text { execution of my duty to the } \\
\text { patient" }\end{array}$ \\
\hline $\begin{array}{l}\text { The duty to } \\
\text { comply with } \\
\text { the } \\
\text { requirements of } \\
\text { professional } \\
\text { ethics and } \\
\text { deontology, to } \\
\text { keep medical } \\
\text { secret }\end{array}$ & $\begin{array}{l}\text { "to work diligently } \\
\text { where the interest of } \\
\text { society require it"; } \\
\text { "to treat the patient } \\
\text { carefully and } \\
\text { attentively, save } \\
\text { medical secret" }\end{array}$ & $\begin{array}{l}\text { "Doctor must always maintain the } \\
\text { highest standards of professional } \\
\text { activity"; } \\
\text { "Doctor ought to be honest with } \\
\text { patients, must deal with the } \\
\text { professional and personal } \\
\text { shortcomings of other doctors, } \\
\text { should expose the deception and } \\
\text { fraud"; } \\
\text { "Doctor should respect the rights } \\
\text { of the patient, colleagues, other } \\
\text { medical staff, and must adhere to } \\
\text { the confidentiality of the patient"; } \\
\text { "Doctor must keep in absolute } \\
\text { secret everything what he knows } \\
\text { about the patient, even after his } \\
\text { death" }\end{array}$ & $\begin{array}{l}\text { " dedicate own life to the } \\
\text { good of man"; } \\
\text { "save entrusted secrets, even } \\
\text { after patient's death" }\end{array}$ \\
\hline $\begin{array}{l}\text { The duty to } \\
\text { spread } \\
\text { scientific and } \\
\text { medical } \\
\text { knowledge } \\
\text { among the } \\
\text { population }\end{array}$ & $\begin{array}{l}\text { "to apply, when it is } \\
\text { required by the } \\
\text { interests of the } \\
\text { patient, for advice to } \\
\text { colleagues and never } \\
\text { refuse them in advice } \\
\text { and help"; } \\
\text { "to save and develop } \\
\text { noble traditions of } \\
\text { national medicine" }\end{array}$ & $\begin{array}{l}\text { "Doctor must give the patient all } \\
\text { sources of his knowledge. If the } \\
\text { doctor does not have possibility } \\
\text { to do diagnostics or treatment, he } \\
\text { should involve another doctor } \\
\text { who has such opportunities"; } \\
\text { "Doctor should be very careful } \\
\text { when disseminating discoveries, } \\
\text { new technologies, or other } \\
\text { treatment techniques, to non- } \\
\text { professional sources of } \\
\text { information" }\end{array}$ & $\begin{array}{l}\text { "to affirm the honest and } \\
\text { noble traditions of the } \\
\text { medical profession by all } \\
\text { means available to me"; } \\
\text { "in spite of everything, to } \\
\text { affirm human life from the } \\
\text { very beginning as the highest } \\
\text { value, and not use own } \\
\text { doctor's knowledge contrary } \\
\text { to the laws of humanity" }\end{array}$ \\
\hline $\begin{array}{l}\text { The duty } \\
\text { constantly to } \\
\text { increase the } \\
\text { level of } \\
\text { professional } \\
\text { knowledge and } \\
\text { skills }\end{array}$ & $\begin{array}{l}\text { "constantly approve } \\
\text { own medical } \\
\text { knowledge and } \\
\text { doctor's skills, to } \\
\text { promote the } \\
\text { development of } \\
\text { medical science and } \\
\text { practice by own } \\
\text { work" }\end{array}$ & $\begin{array}{l}\text { "Doctor must always perform the } \\
\text { highest standards of professional } \\
\text { activity" }\end{array}$ & $\begin{array}{l}\text { "to dedicate own life to the } \\
\text { service of the good of man" }\end{array}$ \\
\hline
\end{tabular}

The shown above characteristics give grounds to assert that the Physician's Oath of Ukraine fully complies with international legal standards in the field of bioethics, including the International Physician's Oath (1948) and the International Code of Medical Ethics (1949). 


\section{DISCUSSIONS}

Having used the interdisciplinary integration approach in the process of training of future medical specialists, from the given example it becomes clear that the universal approach, using method of comparative analysis, development of creative and logical thinking, integration of the received knowledge, skills and abilities into one whole, increases independence of future specialists in medicine, gives grounds for further development of their analytical and critical types of thinking, which directly affects the quality of education. Confirmation of the outlined position is found in the works of scholars who argue the need to develop legal acts to ensure the proper quality of educational services in the training of medical specialists, with required prior discussion on the basis of social dialogue using international practice and in order to avoid contradictions and gaps in the process of implementing the constitutional and legal guarantees of person's right to education, taking into account all the requirements of the Bologna Process [7, p. 844].

Analytical thinking should be understood as the obligatory nature of the situation with careful consideration of all the positive aspects and their counterbalances, which will lead to independent decision or giving any result in the future. Thus, there is a formation of students' analytical type of thinking in given example. Speaking about development of critical thinking, then it will have its logical continuation in the further thinking of future medical specialists.

Since the three documents analyzed are similar by their essence and establish general moral and deontological principles in the profession of doctor, however, with a fairly careful comparison it is possible to make a conclusion that mentioned sources place different emphasis and priorities and have some differences, which is manifested in the following:

1) the first thing that attracts attention is that the Physician's Oath of Ukraine in the first paragraph establishes the dominance of the interests of society and state, than a person ("to work diligently where the interests of society require it") and the next establish doctor's responsibility not before the patient, but before the Nation and the State. Instead, the International Physician's Oath use rather short and comprehensive definition, which not allow to make a conclusion about prevalence of the interests of society or the state - "to dedicate own life to the service of the good of man". This document also directly declares the dominance of the principle of humanity - in spite of everything, to affirm human life from the very beginning as the highest value and not to use the doctor's knowledge contrary to the laws of humanity;

2) In contrast to the Physician's Oath of Ukraine, the International Physician's Oath and the International Code of Medical Ethics establish a direct duty for doctor to save medical secret even after death;

3) The Physician's Oath of Ukraine contains provisions on the doctor's duty to improve own knowledge and skills, to develop science and practice, to keep and develop traditions of national medicine. The International Physician's Oath does not contain such provisions, instead, it imposes on the doctor the obligation to affirm honest and noble traditions of the medical profession, that is the traditions of the profession as a whole (as the property of people), but not only national ones;

4) The International Code of Medical Ethics pays more attention to practical aspects of doctor's activities in carrying out professional activities. In particular, it establishes provisions on the prohibition of self-promotion and receiving a fee for issuing referrals and recommendations, prevention of the influence of financial interests on professional activities;

5) The Physician's Oath of Ukraine establishes doctor's duty to apply, when the interests of the patient require this, for advice to colleagues and never deny them in advice and assistance. A somewhat similar definition is used in the International Code of Medical Ethics: "doctor must give the patient all sources of his knowledge, if the doctor does not have possibility to do 
diagnostics or treatment, he should involve another doctor who has such opportunities". However, the International Physician's Oath does not adhere to such details of the issue of professional relations and interaction in the medical community, using more general determination of duty just in relation to interaction with colleagues - "to treat as brothers and sisters". The International Code of Medical Ethics describes some aspects of interaction in medical community: the doctor must behave towards his colleagues as he would like them to behave towards him and should not entice patients from colleagues;

6) the International Physician's Oath in contrast to the Physician's Oath of Ukraine and the International Code of Medical Ethics contains provisions on the duty of a doctor to treat his teachers with respect and gratitude;

7) the Physician's Oath of Ukraine strictly establishes the deontological and moral duty of the doctor in the sphere of public and private life: "to confirm the advices, which he will give to others, by your way of life (by your own example)". The International documents do not contain similar in content provision.

Summing up all the mentioned thoughts that have been got as the result of using interdisciplinary integration approach on the basis of connecting analytical and critical thinking, future medical specialist is prepared for a formation of final conclusion that even these three documents form the ethical basis, however, they approach the same issue somewhat differently; contain certain significant differences that must be taken into account in each case when deciding whether a doctor violated certain ethical requirements in the implementation of his professional activity.

\section{CONCLUSION}

Vocation al training of future specialists in medicine is in a dynamic development. This is caused by priority of the improving the quality of medical education. One of the main directions of improving higher medical education is active introduction of the interdisciplinary integration approach into the educational process, which should be the fundamental basis of the methodical concept.

The effectiveness of the integration approach in the training of future medical specialists, in order to improve the quality of their education, requires improvement of the methodical concept in the development of educational and methodological complex of vocational training on the basis of interdisciplinary integration. This is possible to provide taking into account the next factors: social demands to professional activity; the specifics of training at clinical departments and features of mastering non-profile disciplines; providing scientific, informational and methodological support of the educational process; formation and development of future specialists in the medical field of analytical and critical types of thinking. The proposed above will ensure high-quality readiness of future medical specialists for their professional activities.

\section{REFERENCES}

[1] Fedchyshyn, N., Klishch, H., Horpinich, T.\& Yelahina, N. (2018). Echoes of the Herbartianism in Western Ukraine (late 19 th - early 20 th centuries). Cultura. International Journal of Philosophy of Culture and Axiology, 15(1), 103-114.

[2] Melnychuk, I., Kalyniuk, N., Humenna, N., Rohalskyi, I., Yastremska, S., Straznikova, I. \& Bloshchynskyi, I. (2019). Organization of distance learningon "Nursing" specialty: methodological and legal aspects. International Journal of Applied Exercise Physiology, 8(3), 1. 
[3] Melnychuk, I., Mozolev, O., Bloshchynskyi, I., Alieksieiev, O., Romanyshyna, L., Zdanevych, L., Prontenko, K. \& Prontenko, V. (2019). Influence of modern fitness technologies on the state of health and development of motorabilities of 17-19-year-old female students. Journal of Physical Education and Sport. Physical Therapy. Sports Therapy and Reabilitation and Sport, 19, 917-924. online ISSN: 2247 - 806 X; p-ISSN: 2247 - 8051; ISSN - L = 2247 - 8051 @ JPES. Scopus.

[4] Melnychuk, I., Svyd, I., Obod, A., Zavolodko, G., Wójcik, W., Orazalieva, S. \& Ziyatbekova, G. (2019). Assessment of information support quality by "friend or foe" identification systems. Przegląde lektrotechniczny, 4, 127-131. ISSN 0033-2097. R. 95 doi:10.15199/48. 2019.04.22. (Scopus).

[5] Mykytenko, P. V. \& Lapinskii, V. V. (2020). Design of medical informatics interdisciplinary integration. Information Technologies and Learning Tools, 75(1), 26-41.

[6] Olendr, T. \& Horpinich, T. (2018). Tupical Linquistics-Stylistic Features of English Political Discourse. Annals of the University of Craiova. Linquistics and Philology, 1-2, 121-133.

[7] Klaassen, R. G. (2018) Interdisciplinary education: a case study. European Journal of Engineering Education, 43(6), 842-859. DOI: 10.1080/03043797.2018.1442417

[8] The World Medical Association. International Code of Medical Ethics. (1949). URL: https://www.wma.net/policies-post/wma-international-code-of-medical-ethics/internationalcode-of-medical-ethics-1949/

[9] Venkata Naga Satya Surendra Chimakurthi, Efficacy of Augmented Reality in Medical Education, Malaysian Journal of Medical and Biological Research, 6(2) 2019, pp.135-142

[10] Venkata Naga Satya Surendra Chimakurthi, Emerging of Virtual Reality (VR) Technology in Education and Training, Asian Journal of Humanity, Art and Literature, 5(2) 2018, pp.157-166.

[11] Venkata Naga Satya Surendra Chimakurthi, Implementation of Artificial Intelligence Policy in the Field of Livestock and Dairy Farm, American Journal of Trade and Policy, 6(3) 2019, pp.113-118.

[12] The World Medical Association. Declaration of Geneva. (1948). URL: https://www.wma.net/policies-post/wma-declaration-of-geneva/

[13] Vykhrushch, A., Melnychuk, I., Fedchyshyn, N. \& Pylypyshyn, O. (2019). Philosophical and Cultural Aspects of Medical Profession: Philosophical and Conceptual Peculiarities. Cultura. International Journal of Philosophy of Culture and Axiology, 16(1), 165-174. 